
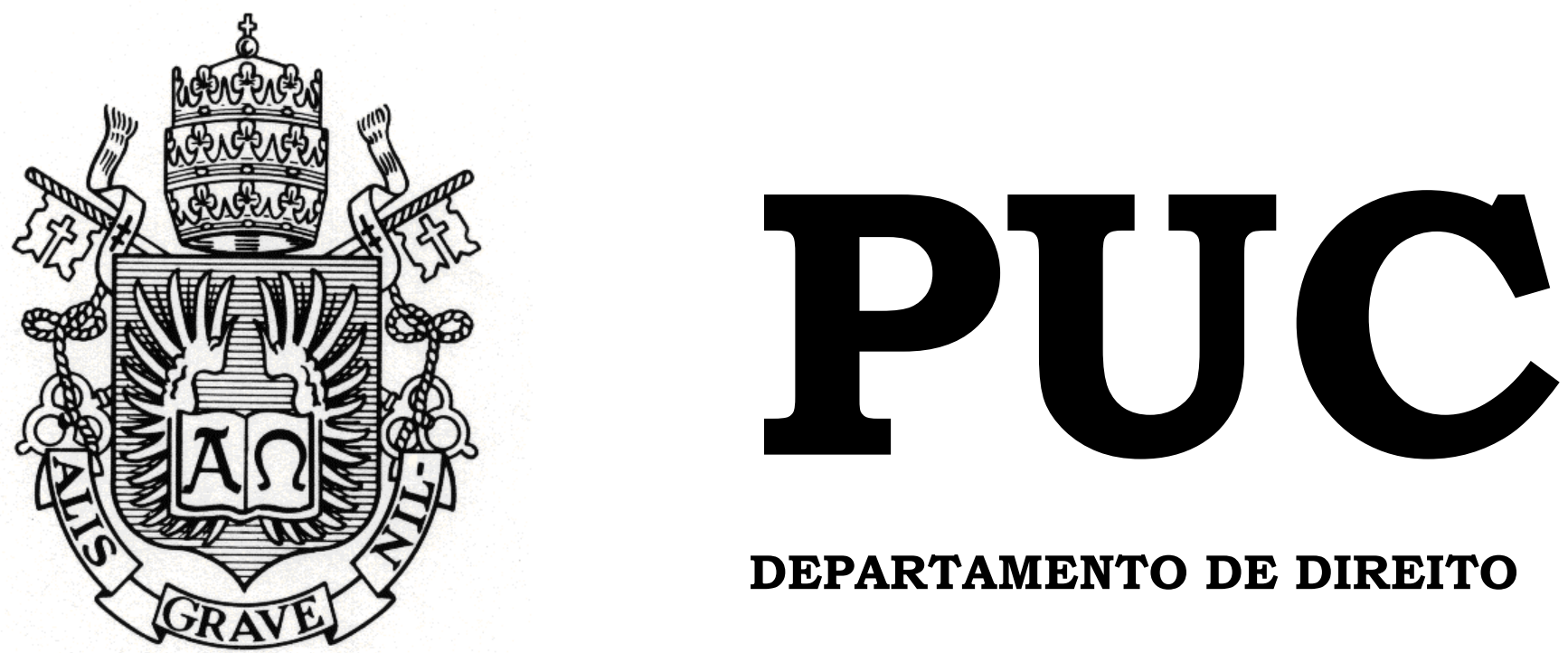

DEPARTAMENTO DE DIREITO

\title{
DA COMPETÊNCIA INDIVIDUAL DO CONSELHEIRO FISCAL E A RELATIVIZAÇÃO DO ÓRGÃO COLEGIADO
}

por

VICTOR SALES DE FIGUEIREDO

ORIENTADORA: Norma Jonssen Parente

2017.1

PONTIFÍCIA UNIVERSIDADE CATÓLICA DO RIO DE JANEIRO

RUA MARQUÊS DE SÃO VICENTE, 225 - CEP 22453-900

RIO DE JANEIRO - BRASIL 


\title{
DA COMPETÊNCIA INDIVIDUAL DO CONSELHEIRO FISCAL E A RELATIVIZAÇÃO DO ÓRGÃO COLEGIADO
}

\author{
por \\ VICTOR SALES DE FIGUEIREDO
}

Monografia

apresentada

ao

Departamento de Direito da Pontificia Universidade Católica do Rio de Janeiro (PUC-Rio) para a obtenção do Título de Bacharel em Direito.

Orientadora: Norma Jonssen Parente 
Alis Grave Nil 


\section{AGRADECIMENTOS}

Primeiramente à Deus, por ter me proporcionado uma vida de oportunidades e felicidade.

À minha mãe, que além de ser a pessoa responsável pela realização dos meus projetos e sonhos, tem a capacidade de manter o amor incondicional por mim, mesmo nos momentos mais difíceis.

Ao meu Tio Getúlio, mais que um tio, um verdadeiro pai.

À minha namorada e amor Catarina, pela paciência, companheirismo e compreensão.

Ao meu pai Celso, que mesmo não estando mais entre nós, continua olhando por mim.

Ao Pedro, Vó Cidinha, e demais membros da Família Sales, que sempre me apoiaram em todos os momentos.

À professora Norma Parente, pela paciência na orientação e incentivo, que tornaram possíveis a conclusão desta monografia.

Ao meu primeiro chefe Emerson Furtado Lima, pela paciência e ensinamentos. Ao meu chefe Alexandre pela inspiração no tema deste trabalho.

Ao Grupo *** Fighting Team, que me mostrou a real prática do direito empresarial.

Aos amigos Bernardo e Thiago, cuja irmandade vem desde 2011. Nossa amizade é um verdadeiro tripé, em que apesar de vivermos separados, sempre seremos uma base para os outros, e se um cair, todos caem.

Aos amigos Matheus, Igor, e Bernardo, sócios do apartamento 402 da Marquês. Obrigado por todos os momentos de amizade.

À Atlética de Direito PUC-Rio, que me proporcionou os melhores anos da minha vida, os quais foram vivenciados ao lado dos melhores amigos que alguém poderia ser apresentado. $\mathrm{Na}$ loucura e camaradagem experimentados ao longo desse anos, descobri que a coisa mais importante da vida são as boas 
histórias, que graças à vocês, são contadas por horas a cada oportunidade que tenho de lembrar desses bons momentos.

Muito obrigado a todos que fizeram parte dessa História. 


\section{RESUMO}

Em primeiro lugar serão feitas breves considerações sobre o direito de fiscalização dos acionistas, suas limitações, importância e evolução histórica no direito brasileiro e no direito comparado. Em seguida, proceder-se-á a uma análise do Conselho Fiscal na qualidade de órgão integrante da estrutura da Companhia, suas características e competências, explorando quais podem ser exercidas por seus membros individualmente, e quais podem ser exercidas exclusivamente pelo órgão colegiado. Por fim, serão apresentadas as peculiaridades do órgão colegiado, bem como os deveres fiduciários a que estão submetidos os conselheiros fiscais, assim como as possibilidades de abuso no exercício da função fiscalizadora.

Palavras Chave: Direito Societário - Mercado de Capitais - Conselho Fiscal Competência individual - Competência concorrente - Princípio majoritário

- Direito de fiscalização. 


\section{SUMÁRIO}

CAPÍTULO 1 - DIREITO DE FISCALIZAÇÃO ............................................ 9

1.1. Fiscalização no Direito Comparado ................................................. 11

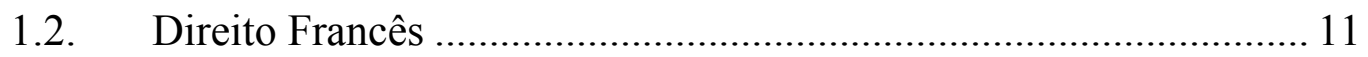

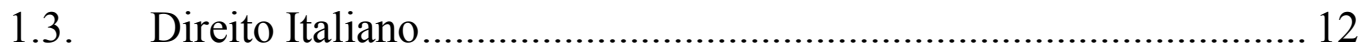

1.4. Direito Norte Americano …………………............................... 13

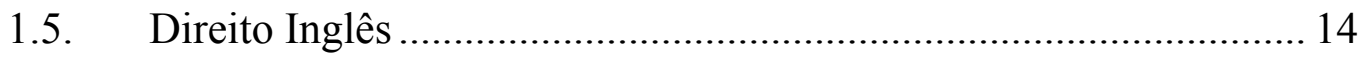

1.6. Fiscalização na História do Brasil ................................................. 14

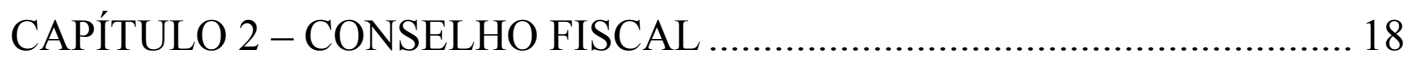

2.1. Natureza Jurídica ........................................................................ 18

2.2. Orgão Colegiado ........................................................................... 19

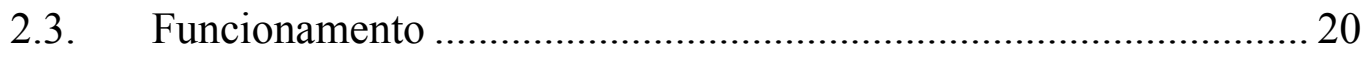

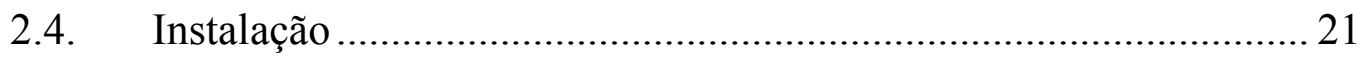

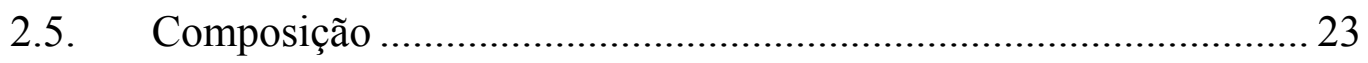

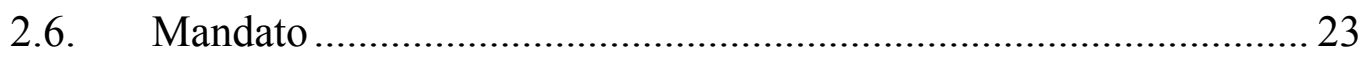

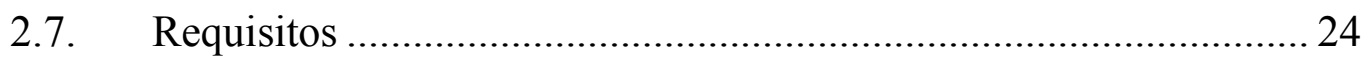

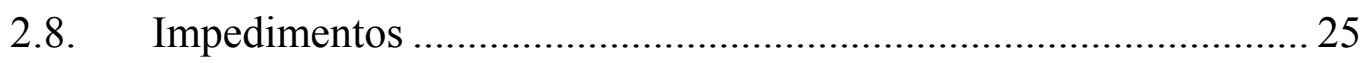

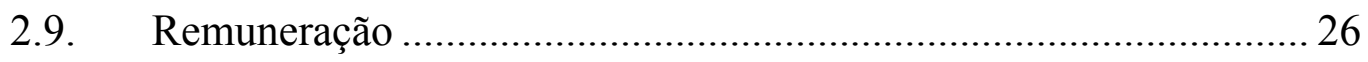

CAPÍTULO 3 - FUNÇÃO E COMPETENCIAS DO CONSELHO FISCAL.. 28

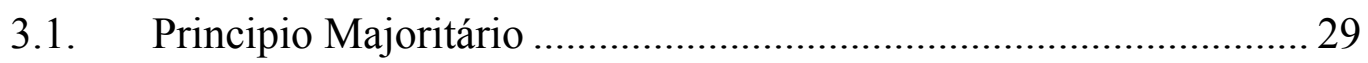

3.2. MODIFICAÇÕES LEGISLATIVAS - LEIS 9.457/97 E 10.303/01 31

3.3. Competencias Individiduais e Concorrentes …………………....... 32

3.4. Limites Da Competência Fiscalizadora............................................ 34 


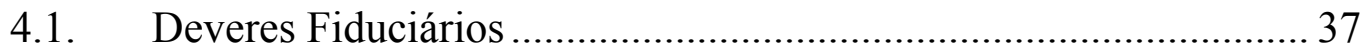

4.2. Dever De Investigar.................................................................. 40

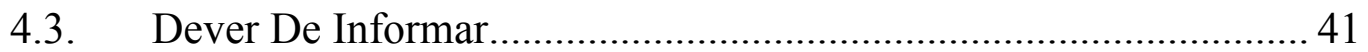

CAPÍTULO 5 - RESPONSABILIDADE DO CONSELHEIRO FISCAL ....... 44 CAPÍTULO 6 - ABUSO NO EXERCICIO DA FUNÇÃO DE CONSELHEIRO

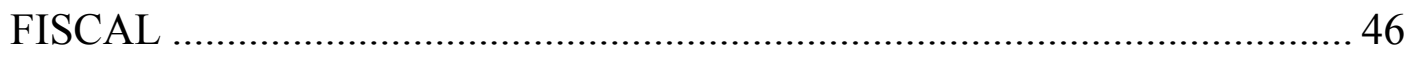

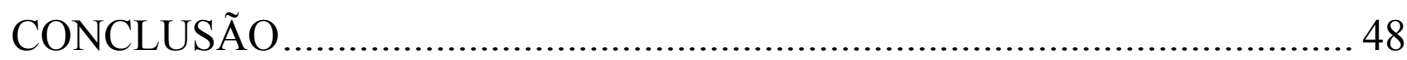

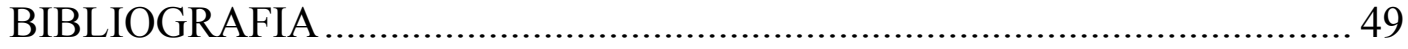




\section{CAPÍTULO 1 - DIREITO DE FISCALIZAÇÃO}

Conforme disposto no art. 109, III $^{1}$ da lei societária, está incluso entre os direitos essenciais do acionista o de "fiscalizar, na forma prevista nesta lei, a gestão dos negócios sociais".

O direito à fiscalização, ao contrário dos direitos essenciais de natureza material, que se esgotam com seu exercício, é constante e representa um instrumento de garantia para os acionistas do exercício seus demais direitos.

Desta forma, seria inócua qualquer previsão normativa sobre os direitos essenciais se não fosse prevista a prerrogativa de se fiscalizar a gestão dos negócios sociais e acompanhar a evolução da situação econômico-financeira da sociedade, da qual depende a preservação do patrimônio dos acionistas.

Entretanto, não é admitido no modelo das sociedades anônimas o direito à fiscalização da gestão dos negócios sociais de maneira irrestrita.

Em todas as legislações é identificada a necessidade de subordinar os membros da administração ao controle e fiscalização exercido por agentes externos, que não sejam participantes dos atos e operações da gestão do patrimônio da companhia.

A possibilidade de garantir poderes ilimitados aos acionistas para exercer seu direito à fiscalização poderia ensejar a paralisação da administração, ou até no impedimento de a companhia de cumprir seu próprio objeto social.

A fiscalização individual de tais atos é na prática impossível de ser exercida pelos acionistas, com o objetivo de prevenir abusos em detrimento da sociedade ou de seus interesses, há a substituição da fiscalização direta pela institucional, seja pela constituição de um órgão, seja pelo controle externo, através de auditores independentes.

\footnotetext{
1 Art. 109. Nem o estatuto social nem a assembleia-geral poderão privar o acionista dos direitos de: (...) III - fiscalizar, na forma prevista nesta Lei, a gestão dos negócios sociais;
} 
O direito de fiscalização pode ser exercido pelos acionistas mediante as seguintes formas previstas na lei societária, conforme lição de Américo Luis Martins da Silva²:

"I. Estabelecendo, em seu art. 133 da Lei $n^{\circ}$ 6.404/76, que antes da realização da assembleia geral ordinária, a administração da companhia deve colocar à disposição dos acionistas para consulta (a) o relatório da administração sobre os negócios sociais e os principais fatos administrativos do exercício findo; (b) a cópia das demonstrações financeiras; (c) o parecer dos auditores independentes, se houver; (d) o parecer do Conselho Fiscal, inclusive votos dissidentes, se houver; e (e) demais documentos pertinentes a assuntos incluídos na ordem do dia da assembleia geral ordinária;

II. Assegurando o direito de os acionistas que representem, no mínimo, um décimo das ações com direito à voto ou cinco por cento das ações sem direito a voto, pedirem a assembleia geral instalação do Conselho Fiscal, quando o seu funcionamento for permanente;

III. Tornando a eleição anual do Conselho Fiscal;

IV. Ordenando que a companhia remeta cópia do relatório da administração sobre os negócios sociais e os principais fatos administrativos do exercício findo, das demonstrações financeiras, parecer dos auditores independentes (se houver), parecer do Conselho Fiscal, demais documentos pertinentes a assuntos incluídos na ordem do dia ao acionista, que representar $5 \%$ ou mais do capital social, que o pedirem por escrito, com a indicação do endereço completo;

V. Concedendo a todos os acionistas o ingresso nas assembleias gerais, a fim de tomar as contas dos administradores, examinar, discutir e votar as demonstrações financeiras;

VI. Determinando que o Conselho Fiscal forneça ao acionista ou grupo de acionistas que representem no mínimo $5 \%$ do capital social, sempre que solicitadas, informações sobre matérias de sua competência;

VII. Assegurando a exibição integral dos livros de escrituração da companhia, quando ordenada judicialmente, mediante requerimento de acionistas que representem 5\% do capital social, para comprovação de atos apontados como violadores da lei ou do estatuto, haja fundada suspeita de graves irregularidades praticadas por qualquer dos órgãos da companhia;

VIII. Outorgando o direito de pedir a dissolução da sociedade por decisão judicial, quando provado que ela não preencha mais seus fins;

IX. Assegurando o direito de qualquer acionista pedir a convocação da assembleia geral nos casos previstos em lei ou no estatuto, quando os administradores retardarem por mais de 60 dias;

$\mathrm{X}$. Assegurando o direito de os acionistas que representam 5\% no mínimo do capital social, pedirem devidamente fundamentado, com indicação das matérias a serem tratadas, a convocação da assembleia geral, quando os administradores não atenderem no prazo de 8 (oito) dias;

XI. Garantindo que os titulares de ações preferenciais sem direito a voto, ou com voto restrito, tenham direito de eleger, em separado, um membro do Conselho Fiscal e respectivo suplente. Igual direito e assegurado aos acionistas minoritários que representem, em conjunto, $10 \%$ ou mais das ações com direito a voto;

2 DA SILVA, Américo Luis Martins. Sociedades Empresarias. $1^{\text {a }}$ ed. Rio de Janeiro: Forense, 2007. $888 \mathrm{p}$. 
XII. Assegurando o direito de promover ação contra acionistas para restituição de dividendos recebidos de ma fé;

XIII. Assegurando o direito de promover qualquer ação contra a companhia, seja qualquer seu fundamento, no prazo de 3 (três) anos."

\subsection{Fiscalização no Direito Comparado}

A fiscalização das atividades dos administradores já era notada nos acordos comerciais celebrados entre diretores e coparticipantes no âmbito das Companhias das Índias Orientais, nos meados do Século XVII.

Após a codificação napoleônica ocorrida no início do século XIX, o instituto da fiscalização perdeu força, uma vez que tal matéria foi esquecida, sendo restaurada pela lei francesa de 1867 , que tornou obrigatória a criação do Conselho Fiscal.

No direito estrangeiro, a partir deste momento, todas as legislações identificaram a necessidade do controle contábil das companhias. Entretanto, ao invés do sistema orgânico de fiscalização, se tem a auditoria externa como método padrão de fiscalização dos atos e contas dos administradores das companhias.

\subsection{Direito Francês}

Conforme disposto nos arts. 218 e seguintes da lei societária francesa de 1966, o sistema de físcalização das companhias é externo, exercido pelos commissaires aux comptes, profissionais inscritos na Ordem dos Peritos Contábeis, agindo individualmente ou coletivamente por meio de sociedade civil de profissionais.

Os comissários têm competência legal para certificar a regularidade das demonstrações financeiras e das contas apresentadas pelos administradores, ao passo que como meio para desempenhar seu trabalho de fiscalização, é dotado de poderes permanentes para verificação dos documentos que julgar 
necessário, podendo recolhe-los e examina-los não somente junto a companhia e seus administradores, mas também junto à quaisquer terceiros que tenham alguma vinculação com os negócios sociais.

São nomeados pela assembleia geral para a fiscalização de seis exercícios sociais. O parecer dos comissários é encaminhado diretamente aos órgãos da administração, cabendo-lhes comunicar imediatamente à assembleia geral qualquer irregularidade ocorrida.

Os comissários são civilmente responsáveis, em face da companhia e de terceiros, pelas consequências de suas ações ou omissões. Entretanto, não são responsáveis pelos atos ilícitos cometidos pelos administradores, a não ser que tinham conhecimento deles e não os revelaram à Assembleia Geral.

Caso haja falsidade em seus relatórios ou deixarem de denunciar os indícios de irregularidades de tenham conhecimento no exercício do seu poder fiscalizatório é prevista à pena de dois anos de prisão e multa.

\subsection{Direito Italiano}

No direito italiano é adotado, como no direito brasileiro, o sistema orgânico de fiscalização, através do collegio sindacale, previsto nos arts. 2.397 e seguintes do Código Civil Italiano.

Com intuito de garantir a eficiência da fiscalização, as companhias tem como requisito a escolha de ao menos um profissional inscrito na Ordem dos Revisores Oficiais, para compor o collegio, de forma a garantir a sua composição técnica.

Caso os acionistas minoritários representantes de ao menos $10 \%$ do capital social encontrarem indícios de irregularidades nos atos da administração e do colégio sindical, poderão denunciar tais fatos ao poder judiciário, que ordenará a inspeção da companhia, podendo chegar ao ponto de uma intervenção judicial com a revogação do mandato dos síndicos e 
administradores e consequente nomeação de administrador judicial, por tempo determinado.

\subsection{Direito Norte Americano}

O direito norte americano adotou o sistema de fiscalização externa através do instituto da auditing, que ao lado da disclosure, constituem as bases do regime jurídico societário norte americano.

Conforme reporta Lamy Filho ${ }^{4}$ :

"A discussão do tema produziu o que chamou de a "batalha das filosofias", entre os que entendiam de agravar penas e fiscalização interna das corporations, para a proteção dos minoritários, (na linha das Blue Sky Laws vigentes em quase todos os estados) e os que sustentavam, (como L. Brandeis) que a solução era aumentar a divulgação e punir a informação privilegiada - que é o maior agravo, ou crime, a que se sujeita o minoritário",

A filosofia do disclosure foi a vencedora nos Estados Unidos, em 1934, com a consequente edição dos Securities Act e a criação da Securities \& Exchange Comission, a conhecida SEC. Também foi desse regime que se retirou o sistema nacional de auditores independentes, encontrado na legislação pátria desde os anos 60.

A fiscalização das demonstrações e contas das companhias e administradores é feita por auditores públicos e independentes, sob a justificativa de que as informações prestadas por eles certificam que tais documentos societários foram apresentados em conformidade com os princípios de contabilidade aceitos.

Os princípios de contabilidade e auditoria tem origem na legislação e regulamentação da SEC, sendo complementados pelo American Institute of Certified Public Accountants. Essa instituição fornece os standards para o exercício da profissão, e a respectiva certification exigida para o exercício.

4 LAMY FILHO, Alfredo. In: Lamy Filho, Alfredo e Bulhões Pedreira, José Luiz. Direito das companhias. Rio de Janeiro: Forense, 2009 vol 1, p. 1264 
A importância dos auditors, organizados em grandes sociedades profissionais é derivada de uma série de exigências no âmbito da SEC e do direito societário, que garante a estes profissionais uma alta estabilidade e independência para o exercício do seu trabalho, o que assegura um alto grau de confiabilidade aos seus relatórios.

\subsection{Direito Inglês}

No direito inglês também é utilizado o sistema de fiscalização externa através dos auditors, conforme matéria constante dos arts. 147 a 158 do Companies Act de 1967, seções 13 e 14.

São escolhidos junto às empresas de contadores, as chartered accountants, instituições extremamente organizadas, que exercem um rígido controle de seus membros, que se tornam os consultores financeiros das companhias.

Os Auditors devem emitir um relatório que deverá variar de acordo com a aprovação ou não das contas analisadas. Será breve no caso de aprovação e descritivo se tiverem reservas sobre tais contas.

\subsection{Fiscalização na História do Brasil}

A Lei $n^{\circ} 3.150$ de 1882 e o Decreto de $n^{\circ} 434$ de 1891 que normatizavam sobre as sociedades anônimas antes do Decreto-lei 2.627/1940, já previam a existência de um sistema orgânico de fiscalização, através de um Conselho Fiscal, eleito pela Assembleia Geral, que tinha a obrigação de proceder ao exame de livros "durante o trimestre que precede a reunião da assembleia geral".

Entretanto, considerando o desprestigio que tinha o órgão, já que muitos à época questionavam a eficiência da sua função fiscalizadora, foi editado o 
Decreto-lei 2.627/1940, que transformou o conselho fiscal em órgão permanente, de funcionamento durante todo o exercício social e assegurava a presença de um representante da minoria, desde que representasse um quinto do capital social.

O diploma de 1940 também adotava o sistema orgânico de fiscalização dos atos dos Administradores, conforme seus arts. 124 e 125, respectivamente:

“Art. 124: A sociedade anônima ou companhia terá um Conselho Fiscal composto de três ou mais membros e suplentes, em igual número, acionistas ou não, residentes no País, eleitos anualmente pela assembleia geral ordinária, os quais poderão ser reeleitos"

"Art. 125: É assegurado aos acionistas dissidentes, que representarem um quinto ou mais do capital social, e os titulares de ações preferenciais, o direito de eleger, separadamente, um dos membros do Conselho Fiscal e o respectivo suplente"

A lei de 1940, em seu art. 124 fixava somente um número mínimo de membros do conselho fiscal, deixando a critério do estatuto da companhia a fixação de quantos poderiam ser eleitos, em contraste com a lei societária atual, que no art. $161, \S 1^{\circ}$, dita que o colegiado será formado de no mínimo três, e no máximo cinco membros, limitando a possibilidade de eleição de membros.

$\mathrm{O}$ art. 125 menciona "acionistas dissidentes", mas a lei nem a doutrina especificava a diferença acionista minoritário e dissidente. Segundo Modesto Carvalhosa $^{6}$,

"dever-se-ia" entender a dissidência, na espécie, como recusa a indicação pelos majoritários de todos os membros do Conselho, mediante a manifestação de vontade da minoria qualificada de eleger representante seu no Conselho Fiscal.”

A lei 6.404/76 manteve o sistema orgânico de fiscalização das finanças da companhia e das contas dos administrados, mas, indo além, exigiu também a auditoria independente para as companhias abertas, conforme art. $177, \S 3^{\circ} 7$.

6 CARVALHOSA, Modesto, Comentários à Lei de Sociedades Anônimas. 3o Volume - Edição revista e atualizada - Artigos 138 a 205, 5a edição - Editora Saraiva, São Paulo, 2011, pág. 498

7 Art. 177 (...) 
Poucos dias antes da edição da lei 6404/76, através da 6.385/76, é criada a Comissão de Valores Mobiliários, que, no seu capítulo VII, trata especificamente dos auditores independentes, objetivando promover o sistema de auditoria independente, obrigando tais empresas a se registrarem na CVM e preparando o caminho para a longa e minuciosa regulação que se lhe seguiu.

Segundo a Exposição de motivos da lei societária, as alterações na estrutura do Conselho Fiscal das companhias foram propostas de acordo com as experiências obtidas a partir da aplicação do Decreto-lei 2.627/1940.

Segundo o documento, em quase todas as companhias os membros do conselho fiscal eram eleitos pelos acionistas controladores, também responsáveis pela escolha dos administradores, o que tornava parcial o funcionamento do órgão.

O órgão sempre foi visto como instrumento de proteção ao acionista dissidente, sempre que estes usassem o seu direito de eleger em separado um dos membros do Conselho, e desde que o conselheiro indicado por esta minoria tenha as condições necessárias para utilizar com eficiência os meios previstos na lei para fiscalizar os atos dos administradores.

Desta forma, com o objetivo de outorgar essa eficiência ao órgão, o projeto de lei manteve a obrigatoriedade de as companhias abertas ou fechadas criarem o conselho fiscal, , cujo funcionamento entretanto seria, permanente ou não, ou apenas quando solicitado pelos acionistas minoritários nos termos do art. $161^{8}$ da lei societária, e também caso forem companhias abertas, a

§ 3o As demonstrações financeiras das companhias abertas observarão, ainda, as normas expedidas pela Comissão de Valores Mobiliários e serão obrigatoriamente submetidas a auditoria por auditores independentes nela registrados. (Redação dada pela Lei n 11.941 , de 2009)

8 Art. 161. A companhia terá um conselho fiscal e o estatuto disporá sobre seu funcionamento, de modo permanente ou nos exercícios sociais em que for instalado a pedido de acionistas.

$\S 1^{\circ} \mathrm{O}$ conselho físcal será composto de, no mínimo, 3 (três) e, no máximo, 5 (cinco) membros, e suplentes em igual número, acionistas ou não, eleitos pela assembléia-geral.

$\S 2^{\circ} \mathrm{O}$ conselho fiscal, quando o funcionamento não for permanente, será instalado pela assembléiageral a pedido de acionistas que representem, no mínimo, 0,1 (um décimo) das ações com direito a voto, ou 5\% (cinco por cento) das ações sem direito a voto, e cada período de seu funcionamento terminará na primeira assembléia-geral ordinária após a sua instalação. 


\section{obrigatoriedade de submeterem suas demonstrações financeiras a auditoria} externa.

$\S 3^{\circ} \mathrm{O}$ pedido de funcionamento do conselho fiscal, ainda que a matéria não conste do anúncio de convocação, poderá ser formulado em qualquer assembléia-geral, que elegerá os seus membros.

$\S 4^{\circ} \mathrm{Na}$ constituição do conselho fiscal serão observadas as seguintes normas:

a) os titulares de ações preferenciais sem direito a voto, ou com voto restrito, terão direito de eleger, em votação em separado, 1 (um) membro e respectivo suplente; igual direito terão os acionistas minoritários, desde que representem, em conjunto, $10 \%$ (dez por cento) ou mais das ações com direito a voto;

b) ressalvado o disposto na alínea anterior, os demais acionistas com direito a voto poderão eleger os membros efetivos e suplentes que, em qualquer caso, serão em número igual ao dos eleitos nos termos da alínea a, mais um.

$\S 5^{\circ}$ Os membros do conselho fiscal e seus suplentes exercerão seus cargos até a primeira assembléiageral ordinária que se realizar após a sua eleição, e poderão ser reeleitos.

$\S 60$ Os membros do conselho fiscal e seus suplentes exercerão seus cargos até a primeira assembléiageral ordinária que se realizar após a sua eleição, e poderão ser reeleitos. (Incluído pela Lei $\mathrm{n}^{\circ} 10.303$, de 2001)

§ 7o A função de membro do conselho fiscal é indelegável. (Incluído pela Lei nº 10.303, de 2001) 


\section{CAPÍTULO 2 - CONSELHO FISCAL}

\subsection{Natureza Jurídica}

O conselho fiscal é o órgão da companhia, previsto em lei, destinado a exercer o controle e a fiscalização da contabilidade social e das contas dos administradores e verificar o cumprimento dos seus deveres legais e estatutários.

É órgão integrante da estrutura da companhia, regulado por normas cogentes, que compreende, além do Conselho Fiscal, a Assembleia Geral e os órgãos da administração,

Ele não atua em nome de terceiros, ou seja, nem da administração, nem dos acionistas, bem como não está subordinado a nenhum deles, estando submetido somente à assembleia geral, que conforme disposto no art. 122, II $^{9}$ da lei societária, tem competência para eleger e destituir seus membros. Em contrapartida, o conselho fiscal não tem poderes sobre tais órgãos da administração, que somente deverão acatar suas solicitações se e na medida em que estiverem dentro do seu escopo legal e estatutário.

Seus membros não atuam como procuradores da companhia, uma vez que não tem o poder de praticar atos jurídicos no exercício da sua função fiscalizadora.

Os membros do conselho fiscal possuem relação jurídica com a companhia, no que tange nomeação, destituição, mandato, deveres-poderes e responsabilidades, mas é o próprio conselho fiscal, e não seus membros, que detém a qualidade de órgão da companhia, enquanto aparelho legalmente constituído. Desta forma, o órgão é juridicamente irresponsável, mas

\footnotetext{
9 Art. 122. Compete privativamente à assembleia geral: (Redação dada pela Lei $\mathrm{n}^{\circ}$ 12.431, de 2011). (...) disposto no inciso II do art. 142; (Redação dada pela Lei ${ }^{\circ} 10.303$, de 2001)
} 
respondem seus membros pelos atos que praticarem, nos termos do art. 165 da Lei $6.404 / 76$.

Sua qualificação como órgão é derivada da forma de eleição, substituição e destituição de seus integrantes, bem como por suas deliberações serem tomadas mediante voto. Além do que, nele vige o princípio majoritário, o qual é relativizado pela possibilidade de atuação individual dos conselheiros, nos casos previstos na lei societária, conforme será explicitado neste estudo.

\section{2. Órgão Colegiado}

O Conselho Fiscal, tal como a Assembleia Geral e o Conselho de Administração, é um órgão colegiado, cujas deliberações são feitas em reuniões regularmente convocadas e instaladas, por maioria de votos dos seus membros.

Entretanto, o colegiado é órgão de natureza particular, uma vez que nele é admitida a atuação individual dos seus membros. A lei societária optou por um órgão de formato hibrido que ora se manifesta de forma colegiada, ora mediante atos singulares de seus membros.

Em contraste, os atos deliberativos isolados de qualquer de seus membros não terão eficácia, sem prejuízo do seu poder de diligencia que, individualmente, cabe ao membro do colegiado fiscalizar, denunciar, efetuar diligencias, votar e solicitar informações aos administradores sobre todos os documentos sociais.

Nesta linha, considerando a qualidade colegial do órgão, a vontade do Conselho Fiscal é distinta de seus membros. Delibera de forma eficaz o colegiado, independente da opinião individual de seus membros, e mesmo com a ausência de alguns deles, desde que observado o quórum mínimo de instalação. Desta forma, a reunião do Conselho Fiscal regularmente convocada 
e instalada representada a universalidade de seus membros, significando as deliberações tomadas, por maioria absoluta dos presentes, a vontade do órgão.

Conforme Modesto Carvalhosa ${ }^{10}$ :

"O fato de possuírem os seus membros poder individual de diligencia não desnatura o caráter colegial do órgão, pois este manifesta sua vontade pelo regime de deliberação majoritária, decidindo eficazmente mediante reunião devidamente convocada e desde que se verifique o quórum de instalação e de deliberação"

\subsection{Funcionamento}

O conselho fiscal é órgão necessário e permanente, entretanto tem seu funcionamento facultativo, como já mencionado.

É órgão necessário porque a lei societária tornou obrigatória a sua instituição pelo estatuto social da companhia. A não previsão da matéria no estatuto o torna invalido, sendo hipótese de indeferimento do pedido de arquivamento pela junta comercial competente, resultando na nulidade na constituição da companhia.

É órgão permanente, embora a lei interna da companhia possa tornar seu funcionamento facultativo, sendo de competência da assembleia geral a sua instalação a pedido de acionistas minoritários ou dos titulares de ações preferenciais sem direito à voto, para que funcione naquele respectivo exercício social, exceto nas sociedades de economia mista, que conforme disposto no art. $240^{13}$ da lei societária, tem seu funcionamento permanente obrigatório, sendo que dois de seus membros serão eleitos pelos minoritários, um pelos ordinaristas, e outro pelos preferencialistas.

Cabe ressaltar que não há obrigatoriedade do seu funcionamento nem nas companhias abertas, nem nas companhias em liquidação, salvo se

10 Carvalhosa, M., \& Kuyven, L. F. (2016). Sociedades Anônimas (Coleção Tratado de Direito Empresarial) (Vol. 3). São Paulo: Revista dos Tribunais. p. 924.

13 Art. 240. O funcionamento do conselho fiscal será permanente nas companhias de economia mista; um dos seus membros, e respectivo suplente, será eleito pelas ações ordinárias minoritárias e outro pelas ações preferenciais, se houver. 
determinado pelo estatuto ou se solicitado pelos acionistas, conforme previsto no artigo $208^{14}$ da lei $6.404 / 76$.

Segundo lição de Modesto Carvalhosa ${ }^{15}$ :

"Ao possibilitar o funcionamento não permanente do órgão, a lei societária lhe conferiu eficiência, na medida em que os minoritários e preferencialistas, quando interessados, é que tornarão o órgão instrumento ativo e, portanto, efetivo de controle da legalidade e legitimidade dos atos dos administradores, ou seja, em favor do interesse social e contra abuso e desvio de poder"

A lei societária não dispõe sobre diversos aspectos do funcionamento do Conselho Fiscal, como investidura de seus membros, convocação e instalação das reuniões do órgão, escolha de presidente, data de reuniões.

Desta forma, é possível que o estatuto social cumpra essa lacuna e disponha sobre estes aspectos, mas tal fato não é comum, de forma que a caso a lei interna da companhia também seja omissa, se aplicarão ao conselho fiscal por analogia as normas sobre funcionamento dos demais órgãos colegiados da companhia.

Nesta linha, também é possível que a regulamentação do regime legal do Conselho Fiscal conste de regimento interno do órgão, por ele aprovado.

\subsection{Instalação}

Quando o funcionamento do órgão não for permanente, a sua instalação ocorrerá na mesma assembleia em que o pedido de acionistas que representem, no mínimo, 10\% (dez por cento) das ações com direito a voto, ou 5\% (cinco por cento) das ações sem direito a voto, nos termos do art. 161, $\S 2^{\circ}$ da lei

14 Art. 208. Silenciando o estatuto, compete à assembleia-geral, nos casos do número I do artigo 206, determinar o modo de liquidação e nomear o liquidante e o conselho fiscal que devam funcionar durante o período de liquidação.

$\S 1^{\circ}$ A companhia que tiver conselho de administração poderá mantê-lo, competindo-lhe nomear o liquidante; o funcionamento do conselho fiscal será permanente ou a pedido de acionistas, conforme dispuser o estatuto.

(...)

15 Carvalhosa, M., \& Kuyven, L. F. (2016). Sociedades Anônimas (Coleção Tratado de Direito Empresarial) (Vol. 3). São Paulo: Revista dos Tribunais. p. 927. 
societária. O pedido de instalação não necessita de qualquer fundamentação, já que o ato é legitimo exercício do seu direito de fiscalização.

É importante ressaltar que esta norma foi parcialmente revogada com a inserção de nova regra no art. $123, \mathrm{~d}^{17}$, da lei societária, introduzida pela lei 9.457/97 a qual prevê que qualquer acionista com 5\% (cinco por cento) de participação no capital social da companhia, independente de ser composto por ações votantes ou não votantes, tem direito à convocar a Assembleia Geral para a instalação do Conselho Fiscal, no caso dos administradores não acolham seu pedido no prazo de oito dias. Não é tangível que o conclave, uma vez convocado, não pudesse instalar o conselho fiscal sob a justificativa de que não teria o quórum legal mínimo exigido pelo art. 161, $\S 2^{\circ}$ para sua instalação. Desta maneira, tal diploma legal foi derrogado por incompatibilidade com a nova norma, fincando uniformizados os percentuais exigidos para requerimento de instalação do conselho fiscal em 5\% (cinco por cento) de ações votantes ou não votantes.

Com o objetivo de assegurar que a qualquer tempo os acionistas minoritários possam solicitar a instalação do órgão, sem nenhuma formalidade especifica, a lei societária assegurou, nos termos do art. $163, \S 3^{{ }^{18}}$, que o seu pedido de funcionamento pode ser apresentado em qualquer assembleia geral, ordinária ou extraordinária, não havendo necessidade da matéria constar no anuncio de convocação nem na ordem do dia.

17 Art. 123. Compete ao conselho de administração, se houver, ou aos diretores, observado o disposto no estatuto, convocar a assembléia-geral.

(...)

d) por acionistas que representem cinco por cento, no mínimo, do capital votante, ou cinco por cento, no mínimo, dos acionistas sem direito a voto, quando os administradores não atenderem, no prazo de oito dias, a pedido de convocação de assembléia para instalação do conselho fiscal. (Incluída pela Lei $\mathrm{n}^{\circ}$ 9.457, de 1997)

18 Art. 163.

(...)

$\S 3^{\circ}$ Os membros do conselho fiscal assistirão às reuniões do conselho de administração, se houver, ou da diretoria, em que se deliberar sobre os assuntos em que devam opinar (ns. II, III e VII). 


\subsection{Composição}

Conforme disposto no $\S 1^{\circ}$ do art. 161 da lei societária, o Conselho Fiscal será composto por, no mínimo, 3 (três), e no máximo, 5 (cinco), membros e suplentes em igual número, acionistas ou não, eleitos pela Assembleia Geral.

A flexibilidade relativa prevista neste dispositivo tem por objetivo permitir que os acionistas controladores possam sempre eleger a maioria dos conselheiros, uma vez que de acordo com a redação no $\S 4^{\circ}$ do art. 161 , os titulares de ações preferenciais sem direito a voto, ou com voto restrito, terão direito de eleger 1 (um) membro e respectivo suplente, bem como os minoritários com direito a voto terão direito de eleger outro membro.

Desta forma, a variação entre o mínimo e o máximo, dependerá nas eleições do Conselho Fiscal, do exercício pelos titulares de ações preferenciais e minoritários do seu direito de eleger um membro cada em votação em separado.

Em consequência, não cabeao estatuto dispor sobre o número de membros do conselho, e caso ele disponha que o colegiado será composto por três membros, aplica-se a norma legal, por se tratar de norma cogente, de ordem pública, sendo eleitos 5 (cinco), membros.

Conforme leciona Lamy Filho ${ }^{19}$ :

"Como essas normas da lei são cogentes, ainda que o estatuto estipule que o Conselho terá o número mínimo de 3 membros, se a companhia tiver emitido ações preferenciais e seus titulares, bem como os minoritários, elegerem 2 membros, a maioria terá direito, com fundamento na norma legal, de eleger 3 membros"

\subsection{Mandato}

19 LAMY FILHO, Alfredo. In: Lamy Filho, Alfredo e Bulhões Pedreira, José Luiz. Direito das Companhias. Rio de Janeiro: Forense, 2009 vol. 1, p. 1271 
O Conselho Fiscal tem funcionamento periódico anual, correspondente à um exercício fiscal da companhia. Considerando que o seu pedido de instalação pode ser apresentado em qualquer assembleia geral ordinária ou extraordinária, funcionará até a primeira assembleia geral ordinária que se realizar depois de sua instalação.

Desta forma, os membros do Conselho Fiscal são eleitos para exercer seus cargos até a primeira Assembleia Geral Ordinária que se realizar após a sua eleição, podendo ser reeleitos nos termos do $\S 6^{\circ}$ do art. 161 da lei societária.

\subsection{Requisitos}

Com o objetivo de garantir eficácia ao órgão colegiado, a lei societária no seu art. $162^{21}$ estabeleceu requisitos de competência e experiência para o exercício da função de conselheiro fiscal.

Somente podem ser eleitas para o Conselho Fiscal pessoas naturais, residentes no país, diplomadas em nível superior, ou que tenham exercido, pelo prazo mínimo de três anos, cargo de administrador de empresa ou conselho fiscal.

21 Art. 162. Somente podem ser eleitos para o conselho fiscal pessoas naturais, residentes no País, diplomadas em curso de nível universitário, ou que tenham exercido por prazo mínimo de 3 (três) anos, cargo de administrador de empresa ou de conselheiro fiscal.

$\S 1^{\circ}$ Nas localidades em que não houver pessoas habilitadas, em número suficiente, para o exercício da função, caberá ao juiz dispensar a companhia da satisfação dos requisitos estabelecidos neste artigo. $\S 2^{\circ}$ Não podem ser eleitos para o conselho fiscal, além das pessoas enumeradas nos parágrafos do artigo 147, membros de órgãos de administração e empregados da companhia ou de sociedade controlada ou do mesmo grupo, e o cônjuge ou parente, até terceiro grau, de administrador da companhia.

$\S 3^{\circ}$ A remuneração dos membros do conselho fiscal, além do reembolso, obrigatório, das despesas de locomoção e estada necessárias ao desempenho da função, será fixada pela assembléia-geral que os eleger, e não poderá ser inferior, para cada membro em exercício, a dez por cento da que, em média, for atribuída a cada diretor, não computados benefícios, verbas de representação e participação nos lucros. (Redação dada pela Lei no ${ }^{\circ}$.457, de 1997) 
Considerando as disparidades regionais do país, tais requisitos são dispensáveis no caso de não haverem na localidade pessoas que atendam as qualificações exigidas.

Neste caso é necessário, através de processo de jurisdição voluntária, que o juízo da localidade dispense a companhia da satisfação destes requisitos. Vale lembrar que não é necessário que seus membros também sejam acionistas da companhia, muito pelo contrário, para garantir a autonomia e independência do órgão no exercício de suas atribuições, é extremamente recomendável que seus membros não sejam acionistas ou agregados, de forma a evitar conflitos de interesses.

\subsection{Impedimentos}

Conforme disposto no art. 162, $\S 2^{\circ}$ da lei societária, além dos impedimentos gerais enumerados no art. $147^{22}$, aplicáveis aos administradores, há outros específicos relacionados à função de conselheiro físcal, cuja presença, presume a lei, afetará a imparcialidade do conselheiro.

Conforme reflexão de Eizirik ${ }^{23}$ :

22 Art. 147. Quando a lei exigir certos requisitos para a investidura em cargo de administração da companhia, a assembléia-geral somente poderá eleger quem tenha exibido os necessários comprovantes, dos quais se arquivará cópia autêntica na sede social.

$\S 1^{\circ}$ São inelegíveis para os cargos de administração da companhia as pessoas impedidas por lei especial, ou condenadas por crime falimentar, de prevaricação, peita ou suborno, concussão, peculato, contra a economia popular, a fé pública ou a propriedade, ou a pena criminal que vede, ainda que temporariamente, o acesso a cargos públicos.

$\S 2^{\circ}$ São ainda inelegíveis para os cargos de administração de companhia aberta as pessoas declaradas inabilitadas por ato da Comissão de Valores Mobiliários.

§ 3o O conselheiro deve ter reputação ilibada, não podendo ser eleito, salvo dispensa da assembléiageral, aquele que: (Incluído pela Lei $\mathrm{n}^{\circ} 10.303$, de 2001)

I - ocupar cargos em sociedades que possam ser consideradas concorrentes no mercado, em especial, em conselhos consultivos, de administração ou fiscal; e (Incluído pela Lei $\mathrm{n}^{\circ} 10.303$, de 2001)

II - tiver interesse conflitante com a sociedade. (Incluído pela Lei $\mathrm{n}^{\circ} 10.303$, de 2001)

§ 4o A comprovação do cumprimento das condições previstas no $\S 3$ o será efetuada por meio de declaração firmada pelo conselheiro eleito nos termos definidos pela Comissão de Valores Mobiliários, com vistas ao disposto nos arts. 145 e 159, sob as penas da lei. (Incluído pela Lei ${ }^{\circ} 10.303$, de 2001)

23 EIZIRIK, Nelson. A Lei das S/A Comentada. Volume II - Artigos 121 a 188 . São Paulo: Quartier Latin, 2011, p. 437 
"O objetivo da norma é o de evitar que o conselho fiscal não cumpra adequadamente as suas funções de fiscalização, em virtude dos vínculos de subordinação ou de dependência, evitando-se, assim, situações que caracterizem o conflito de interesses"

Desta forma, também estão impedidos de ser membros do colegiado: (i) membros da administração; (ii) cônjuge ou parente, até terceiro grau, de administrador da companhia; e (iii) pessoas que possuam vínculo empregatício com a companhia, com coligadas ou sociedades pertencentes ao grupo de fato ou de direito.

\subsection{Remuneração}

No tocante à remuneração dos membros do conselho fiscal, a lei societária, nos termos do previsto no $\S 3^{\circ}$ do art. 162 , não poderá ser inferior, para cada membro em exercício, a $10 \%$ da que, em média, for atribuída para cada diretor, não computados benefícios, verbas de representação e participação nos lucros.

Essa forma de remuneração foi estabelecida de forma diversa dos administradores, uma vez que considerando a natureza dos serviços e a responsabilidade do conselheiro fiscal, esta deverá ser compensatória. Ademais, não devem os conselheiros ter interesse patrimonial nos resultados financeiros da gestão da companhia, motivo pelo qual a norma legal não contempla a sua participação nos lucros sociais ou na remuneração indireta dos administradores.

Conforme consideração de Carvalhosa ${ }^{25}$,

"Essa participação não seria, com efeito, admissível, porque subordinaria a remuneração dos conselheiros ou pelo menos parte dela, à existência de lucros, induzindo-os a aceitar, em seus pareceres, a existência de lucros fictícios".

25 CARVAlhosA, Modesto, Comentários à Lei de Sociedades Anônimas. $3^{\circ}$ Volume - Edição revista e atualizada - Artigos 138 a 205, $5^{\mathrm{a}}$ edição - Editora Saraiva, São Paulo, 2011, pág. 523 
Ademais, terão direito os membros do colegiado ao reembolso das despesas de locomoção e estadia necessárias ao desempenho da função, conforme disposto no art. $162, \S 3^{\circ}$. 


\title{
CAPÍTULO 3 - FUNÇÃO E COMPETENCIAS DO CONSELHO FISCAL
}

\author{
A função primária do conselho fiscal é a fiscalização e controle da dos \\ atos dos administradores, em relação as contas, à legalidade, à legitimidade, \\ interesse social, e desvio de poder informação aos acionistas e revisão das \\ contas.
}

As disposições legais sobre atribuições do Conselho Fiscal, dispostos no art, no art. $163^{27}$ da lei societária, permitem classificar suas funções em cinco categorias, conforme classificação de Lamy Filho ${ }^{28}$ :

27 Art. 163. Compete ao conselho fiscal:

I - fiscalizar, por qualquer de seus membros, os atos dos administradores e verificar o cumprimento dos seus deveres legais e estatutários; (Redação dada pela Lei $n^{\circ} 10.303$, de 2001)

II - opinar sobre o relatório anual da administração, fazendo constar do seu parecer as informações complementares que julgar necessárias ou úteis à deliberação da assembléia-geral;

III - opinar sobre as propostas dos órgãos da administração, a serem submetidas à assembléia-geral, relativas a modificação do capital social, emissão de debêntures ou bônus de subscrição, planos de investimento ou orçamentos de capital, distribuição de dividendos, transformação, incorporação, fusão ou cisão; (Vide Lei n ${ }^{\circ} 12.838$, de 2013)

IV - denunciar, por qualquer de seus membros, aos órgãos de administração e, se estes não tomarem as providências necessárias para a proteção dos interesses da companhia, à assembléia-geral, os erros, fraudes ou crimes que descobrirem, e sugerir providências úteis à companhia; (Redação dada pela Lei $\mathrm{n}^{\circ} 10.303$, de 2001)

V - convocar a assembléia-geral ordinária, se os órgãos da administração retardarem por mais de 1 (um) mês essa convocação, e a extraordinária, sempre que ocorrerem motivos graves ou urgentes, incluindo na agenda das assembléias as matérias que considerarem necessárias;

VI - analisar, ao menos trimestralmente, o balancete e demais demonstrações financeiras elaboradas periodicamente pela companhia;

VII - examinar as demonstrações financeiras do exercício social e sobre elas opinar;

VIII - exercer essas atribuições, durante a liquidação, tendo em vista as disposições especiais que a regulam.

$\S 1^{\circ}$ Os órgãos de administração são obrigados, através de comunicação por escrito, a colocar à disposição dos membros em exercício do conselho fiscal, dentro de 10 (dez) dias, cópias das atas de suas reuniões e, dentro de 15 (quinze) dias do seu recebimento, cópias dos balancetes e demais demonstrações financeiras elaboradas periodicamente e, quando houver, dos relatórios de execução de orçamentos.

§ 2 o O conselho fiscal, a pedido de qualquer dos seus membros, solicitará aos órgãos de administração esclarecimentos ou informações, desde que relativas à sua função fiscalizadora, assim como a elaboração de demonstrações financeiras ou contábeis especiais. (Redação dada pela Lei no 10.303 , de 2001)

$\S 3^{\circ}$ Os membros do conselho fiscal assistirão às reuniões do conselho de administração, se houver, ou da diretoria, em que se deliberar sobre os assuntos em que devam opinar (ns. II, III e VII).

$\S 4^{\circ} \mathrm{Se}$ a companhia tiver auditores independentes, o conselho fiscal, a pedido de qualquer de seus membros, poderá solicitar-lhes esclarecimentos ou informações, e a apuração de fatos específicos. (Redação dada pela Lei no 9.457 , de 1997) 
"I. Fiscalizar os atos dos administradores constantes das normas dos seguintes dispositivos legais: (a) "fiscalizar os atos dos administradores e verificar o cumprimento dos seus deveres legais e estatutários" (art. 163, I); (b) "denunciar aos órgãos da administração e, se estes não tomarem às providencias necessárias para proteção dos interesses da companhia, à Assembleia Geral, os erros, fraudes, ou crimes que descobrirem, e sugerir providencias úteis à companhia" (art. 163, IV); e (c) "analisar, ao menos trimestralmente, o balancete e demais demonstrações financeiras elaboradas periodicamente pela companhia" (art. 163, VI);

II. Opinar sobre os documentos ou propostas de deliberações a serem submetidas à assembleia Geral , constantes das seguintes normas: (a) "opinar sobre o relatório anual da administração , fazendo constar do seu parecer as informações complementares que julgarem necessárias ou úteis à deliberação da Assembleia Geral" (art. 163, II); e (b) "opinar sobre as propostas dos órgãos da administração a serem submetidas à assembleia geral, relativas à modificação do capital social, emissão de debêntures ou bônus de subscrição, planos de investimento ou orçamentos de capital, distribuição de dividendos, transformação, incorporação, fusão ou cisão (art. 163, III);

III. Examinar as demonstrações financeiras no exercício social e sobre elas opinar (art. 163, VII);

IV. Convocar a Assembleia Geral Ordinária, se os órgãos da administração retardarem por mais de um mês essa convocação extraordinária, sempre que ocorrerem motivos graves ou urgentes, incluindo na agenda das assembleias as matérias que considerarem necessárias (art. 163, V); e

Fornecer ao acionista, ou grupo de acionistas que representem, no mínimo, 5\% do capital social, sempre que solicitadas, informações sobre matérias de suas competência (art. $\left.163 \S 6^{\circ}\right)$ "

\subsection{Princípio Majoritário}

Os órgãos colegiados da companhia deliberam por manifestação da vontade de seus membros, e as deliberações da Assembleia Geral e do

\footnotetext{
$\S 5^{\circ} \mathrm{Se}$ a companhia não tiver auditores independentes, o conselho fiscal poderá, para melhor desempenho das suas funções, escolher contador ou firma de auditoria e fixar-lhes os honorários, dentro de níveis razoáveis, vigentes na praça e compatíveis com a dimensão econômica da companhia, os quais serão pagos por esta.

$\S 6^{\circ} \mathrm{O}$ conselho fiscal deverá fornecer ao acionista, ou grupo de acionistas que representem, no mínimo 5\% (cinco por cento) do capital social, sempre que solicitadas, informações sobre matérias de sua competência.

$\S 7^{\circ}$ As atribuições e poderes conferidos pela lei ao conselho fiscal não podem ser outorgados a outro órgão da companhia.

$\S 8^{\circ} \mathrm{O}$ conselho fiscal poderá, para apurar fato cujo esclarecimento seja necessário ao desempenho de suas funções, formular, com justificativa, questões a serem respondidas por perito e solicitar à diretoria que indique, para esse fim, no prazo máximo de trinta dias, três peritos, que podem ser pessoas físicas ou jurídicas, de notório conhecimento na área em questão, entre os quais o conselho físcal escolherá um, cujos honorários serão pagos pela companhia. (Inclú́do pela Lei $\mathrm{n}^{\circ}$ 9.457, de 1997)

28 LAMY FILHO, Alfredo. In: Lamy Filho, Alfredo e Bulhões Pedreira, José Luiz. Direito das Companhias. Rio de Janeiro: Forense, 2009 vol. 1, p. 1273
} 
Conselho de Administração são tomadas pela maioria dos votos de seus membros, conforme disposto nos arts. $129^{29}$ e $140, \mathrm{IV}^{30}$ da lei societária. Ainda que não haja esta previsão expressa nas normas que disciplinam o conselho fiscal, a ele se aplica por analogia.

"A experiência das companhias demonstra que o princípio majoritário nas deliberações colegiadas é essencial ao funcionamento eficiente desse tipo de sociedade e as normas do artigo 161 asseguram a unidade de comando de todos os órgãos da companhia ${ }^{31,}$

Contudo, apesar da lei societária ter atribuído ao conselho fiscal a natureza de órgão colegiado, o principio majoritário nele é relativo, mediante a previsão da atuação individual de seus membros.

"A competência colegial do Conselho Fiscal para todas as suas funções poderia significar a opressão do representante das minorias acionárias; isso não ocorre, porém, por não implicar o regime colegial a exclusão da função individual de seus membros $^{32,}$

A previsão de poderes individuais no âmbito do conselho fiscal tem por objetivo impedir que o acionista controlador, que tem o poder de eleger a maioria dos membros do colegiado, eventualmente frustre a atuação fiscalizadora do conselho fiscal para cobrir a atuação ilícita de administradores. Conforme defende Eizirik $^{33}$ :

"A composição heterogênea do conselho fiscal, que se manifesta na origem de seus membros, apenas faz sentido se for conferida a cada um deles a possibilidade de atuar individualmente. Se o órgão apresentasse uma feição puramente colegiada decidindo

29 Art. 129. As deliberações da assembléia-geral, ressalvadas as exceções previstas em lei, serão tomadas por maioria absoluta de votos, não se computando os votos em branco.

(...)

30 Art. 140. O conselho de administração será composto por, no mínimo, 3 (três) membros, eleitos pela assembléia-geral e por ela destituíveis a qualquer tempo, devendo o estatuto estabelecer:

(...)

IV - as normas sobre convocação, instalação e funcionamento do conselho, que deliberará por maioria de votos, podendo o estatuto estabelecer quorum qualificado para certas deliberações, desde que especifique as matérias. (Redação dada pela Lei n 10.303 , de 2001)

31 LAMY FILHO, Alfredo. In: Lamy Filho, Alfredo e Bulhões Pedreira, José Luiz. Direito das Companhias. Rio de Janeiro: Forense, 2009 vol. 1, p. 1268

32 Carvalhosa, M., \& Kuyven, L. F. (2016). Sociedades Anônimas (Coleção Tratado de Direito Empresarial) (Vol. 3). São Paulo: Revista dos Tribunais,. p. 936

33 EIZIRIK, Nelson. A Lei das S/A Comentada. Volume II - Artigos 121 a 188 . São Paulo: Quartier Latin, 2011, p. 445 
sempre pela maioria e sem a possibilidade de atuação singular de seus membros, os conselheiros não poderiam em alguns casos, exercer as funções para as quais foram eleitos, já que sempre prevaleceria a vontade dos controladores"

\subsection{MODIFICAÇÕES LEGISLATIVAS - LEIS 9.457/97 E 10.303/01}

Ao longo do tempo foram implementadas reformas na lei societária com objetivo de aumentar o escopo de competências individuais do conselheiro individualmente.

A Lei 9.457/97 trouxe duas importantes modificações no âmbito da lei societária: (i) no $\S 4^{\circ}$ do artigo 163 , que atribuía somente ao colegiado a competência de solicitar aos auditores independentes esclarecimentos ou informações e a apuração de fatos específicos, adicionou que o Conselho poderia exercer esta atribuição "a pedido de qualquer de seus membros"; e (ii) criou o pedido de perícia, constante do $\S 8^{\circ}$.

$\mathrm{O}$ acrescentamento do $\S 4^{\circ}$ deixou de forma clara a prerrogativa de diligencia individual dos conselheiros fiscais estabelecida no $\S 2^{\circ}$, entretanto manteve o sistema da lei que estabelece que este tipo de pedido depende de deliberação do órgão.

A nova redação tinha por objetivo por fim ao abuso de direito que cometiam os conselheiros fiscais eleitos pelos acionistas controladores, que para impedir o pleno exercício do direito dever de diligencia individual junto aos auditores independentes negavam trânsito aos pedidos individuais formulados pelos representantes dos acionistas minoritários.

A Lei 10.303/01 mudou a redação dos incisos I e IV do art. 163 da lei societária, e a redação a do parágrafo único do art. $164^{35}$, para dispor que as

35 Art. 164. Os membros do conselho fiscal, ou ao menos um deles, deverão comparecer às reuniões da assembléia-geral e responder aos pedidos de informações formulados pelos acionistas.

Parágrafo único. Os pareceres e representações do conselho fiscal, ou de qualquer um de seus membros, poderão ser apresentados e lidos na assembléia-geral, independentemente de publicação e ainda que a matéria não conste da ordem do dia. (Redação dada pela Lei no 10.303 , de 2001) 
competências dos órgãos dispostas nos referidos dispositivos poderiam ser exercidas "por qualquer de seus membros".

Adicionalmente, alterou o $\$ 2^{\circ}$ do art. 163 para confirmar que os membros do conselho fiscal possam pedir à este que solicite esclarecimentos ou informações aos órgãos da administração, mas "desde que relativas à sua função fiscalizadora".

A nova redação do item I do art. 163 não ampliou os poderes dos membros do conselho, uma vez que a jurisprudência dos nossos tribunais sob a égide da Lei n. 6.404/76 sempre confirmou o alcance da competência individual prevista neste art. 163, atribuída a cada conselheiro fiscal, de per si, de acesso as informações necessárias às atividades de fiscalização e de controle da gestão financeira da companhia ${ }^{36}$.

Entretanto, a nova competência de denúncia "por qualquer de seus membros" caracteriza diferentemente uma modificação importante, já que limita o poder do órgão colegiado de impedir atos individuais ilegais.

\subsection{Competências Individuais e Concorrentes}

A lei societária prevê a competência para atuação concorrente do órgão e do conselheiro fiscal individualmente em algumas hipóteses, e para outras existe somente a competência privativa do órgão.

É da competência dos conselheiros individualmente, segundo lição de Modesto Carvalhosa ${ }^{37}$,:

"I. Fiscalizar os atos dos administradores e verificar o cumprimento de seus deveres legais e estatutários (inciso I);

II. Denunciar aos órgãos da administração e, se estes permanecerem inertes, à assembleia geral, os erros fraudes ou crimes que descobrirem sugerindo providencias úteis à companhia (inciso IV);

36 CARVALHOSA, Modesto, Comentários à Lei de Sociedades Anônimas. 3o Volume - Edição revista e atualizada - Artigos 138 a 205, 5a edição - Editora Saraiva, São Paulo, 2011, pág. 528

37 CARVAlHOSA, Modesto, Comentários à Lei de Sociedades Anônimas. $3^{\circ}$ Volume - Edição revista e atualizada - Artigos 138 a 205, $5^{\text {a }}$ edição - Editora Saraiva, São Paulo, 2011, pág. 528 
III. Solicitar aos órgãos da administração esclarecimentos ou informações, desde que relativas a sua função fiscalizadora, assim como elaboração de demonstrações financeiras ou contábeis especiais $\left(\S 2^{\circ}\right)$

IV. Assistir às reuniões do Conselho de Administração, se houver, ou da diretoria, em que se deliberar sobre os assuntos em que devam opinar previstos nos incisos II, III, VII, e $\S 3^{\circ}$; e

V. Se a companhia tiver auditores independentes, solicitar-lhes esclarecimentos ou informações e a apuração de fatos específicos $\left(\S 4^{\circ}\right)^{\text {”’”. }}$

As demais competências devem ser exercidas colegiadamente (incisos II, III, V, VI, VII, VIII, e parágrafos 5, 6 e 8).

Nas palavras de Eizirik ${ }^{38}$ :

"Há competência do órgão e do conselheiro nos seguintes casos previstos no dispositivo legal: incisos I, IV e parágrafos 2,3 e 4 . A competência é apenas do conselho fiscal nas seguintes hipóteses: incisos II, III, V, VI, VII, VIII, e parágrafos $5,6$ e 8$) "$

De modo geral os atos de análise, opinião, e convocação de assembleia são de competência exclusiva do colegiado, enquanto os atos de fiscalização denúncia e solicitação de informações são de competência concorrente.

Conforme já mencionado, a previsão de competências colegiadas não é impedimento para que qualquer membro do conselho fiscal possa individualmente requerer, e o colegiado em sua maioria é obrigado a acatar o seu pedido. Tal solicitação é vinculante, exceto se comprovado que se trata de um abuso de direito, na qual o pedido visa o benefício próprio do conselheiro ou dos acionistas que o elegeram, em detrimento dos interesses da companhia.

Conforme leciona Lamy Filho ${ }^{40}$ :

"O colegiado tem o dever legal de solicitar as informações pedidas por qualquer dos membros, mas pode recusar a transmissão de pedidos que sejam ilegais - não de contenham nas atribuições do órgão ou evidenciem exercício abusivo de atribuições".

38 EIZIRIK, Nelson. A Lei das S/A Comentada. Volume II - Artigos 121 a 188. São Paulo: Quartier Latin, 2011, p. 447

40 LAMY FILHO, Alfredo. In: Lamy Filho, Alfredo e Bulhões Pedreira, José Luiz. Direito das Companhias. Rio de Janeiro: Forense, 2009 vol. 1, p. 1281 
Nos demais casos, a solicitação de diligencias e verificações por qualquer de seus membros não pode ser negada pela maioria do colegiado.

"A obstrução pela maioria de tais procedimentos fará presumir que os seus membros não estão agindo com independência, procurando evitar o conhecimento de atos eventualmente irregulares. Configurada a obstrução os membros majoritários serão responsabilizados ${ }^{42}$,

\subsection{Limites Da Competência Fiscalizadora}

Conforme disposto no art. 163, I é de competência do conselho fiscal fiscalizar os atos dos administradores e verificar o cumprimento dos seus deveres legais e estatutários. Entretanto, se trata de norma abrangente, na qual não foi definido quais atos dos administradores estariam sob efeito da norma, ou seja, atos de administração propriamente ditos ou atos de gestão empresarial.

Considerando que a lei é silente, a fiscalização e o controle são exercidos sobre os dois grupos, podendo ser relativos à organização societária ou a própria organização empresarial. A organização societária compreende os atos de administração, que consistem na convocação e realização de assembleias gerais, reuniões dos órgãos da administração e arquivamento e publicação de atas. A organização empresarial compreende os atos de gestão do patrimônio da companhia, na verificação da observância das formalidades necessárias para a prática de atos de gestão ordinária, de alienação e oneração de bens da companhia.

Entretanto, não é de competência do conselho fiscal ou de seus membros individualmente apreciar o mérito ou a conveniência empresarial das decisões negociais tomadas pelos administradores.

"A competência do Conselho Fiscal para fiscalizar os administradores não importa na possibilidade de interferência na gestão ordinária conduzida pelos diretores nem na

42 Carvalhosa, M., \& Kuyven, L. F. (2016). Sociedades Anônimas (Coleção Tratado de Direito Empresarial) (Vol. 3). São Paulo: Revista dos Tribunais,. p. 937 
orientação geral dos negócios da companhia, estabelecida pelo conselho de administração",43

O Controle de legalidade constitui o poder que o órgão fiscalizador tem de verificar se os atos de gestão e de representação celebrados pela diretoria, e se as deliberações do conselho de administração estão em consonância com a lei e o estatuto da companhia, bem como se dão cumprimento às deliberações da Assembleia Geral.

Para Modesto Carvalhosa ${ }^{44}$, o Conselho Fiscal também é competente para fazer o controle de legitimidade, o qual

"não se restringe ao aspecto meramente formal da gestão financeira dos administradores, mas analisar a razoabilidade desses negócios financeiros, a fim de verificar a sua consonância com o interesse social e os fins próprios da companhia. Nessa função tem o conselheiro individualmente o poder de inspecionar os documentos contábeis e contratuais, para verificar a consonância e procedência quanto ao valor e efetividade".

O poder de fiscalização do órgão não é amplo ou ilimitado. Não pode o órgão fiscalizador ou seu membro extrapolar o razoável, e a título de abuso de direito fazer solicitações abusivas à companhia e seus administradores.

Conforme supracitado, o $\S 2^{\circ}$ do art. 163, segundo a sua redação reformada pela lei 10.303/01, deixou claro que as informações e esclarecimentos a serem solicitados pelos membros do Conselho Fiscal aos administradores da companhia, deverão ser estritamente relativos à sua função fiscalizadora, com o objetivo de prevenir que o poder-dever de fiscalização do conselheiro fiscal seja utilizado indevidamente por acionistas minoritários como instrumento de pressão ilegítima conta os controladores.

"Assim, o direito de pedir informações é instrumental, diz respeito ao exercício da função fiscalizadora, não podendo, portanto, ser ampliado a ponto de instituir uma 'administração paralela na companhia",

43 EIZIRIK, Nelson. A Lei das S/A Comentada. Volume II - Artigos 121 a 188. São Paulo: Quartier Latin, 2011, p. 448

44 Carvalhosa, M., \& Kuyven, L. F. (2016). Sociedades Anônimas (Coleção Tratado de Direito Empresarial) (Vol. 3). São Paulo: Revista dos Tribunais,. p. 939

46 EIZIRIK, Nelson. A Lei das S/A Comentada. Volume II - Artigos 121 a 188 . São Paulo: Quartier Latin, 2011, p. 448 
Desta forma, a possibilidade de fiscalização a ser exercida pelo conselheiro fiscal sobre os atos dos administradores se restringe à matéria financeira e à verificação do atendimento de seus deveres legais e estatutários exclusivamente neste setor da sociedade.

Nesse sentido, o Tribunal de Justiça de São Paulo, no julgamento da AC $\mathrm{n}^{\mathrm{o}}$ 62.520-1 decidiu:

“(...) A Fiscalização exercida pelo Conselho Fiscal sobre os atos dos administradores centra-se na verificação do atendimento dos seus deveres legais e estatutários. O órgão de fiscalização não tem poderes para apreciar o conteúdo da gestão societária, ou seja, não lhe cabe entrar no julgamento do mérito e da conveniência das decisões empresariais tomadas pelos administradores"

Ademais, a fiscalização é restrita ao exercício social em curso, para o qual o Conselho Fiscal é eleito para exercer suas fiscalizatórias, com o principal objetivo de auxiliar a Assembleia Geral Ordinária na sua Competência de tomar as contas dos administradores relativas ao exercício social terminado, uma vez que, conforme disposto no art. $134, \S 3^{047}$ da lei societária, a aprovação das contas do exercício sem reserva representa uma quitação da companhia aos administradores, salvo erro, dolo fraude ou simulação.

Deste modo, não compete ao colegiado fiscalizar atos e contas referentes períodos da administração já abrangidos por aprovações das assembleias gerais ordinárias anteriores, sob pena de estar exorbitando suas atribuições legais.

47 Art. 134. (...)

$\S 3^{\circ} \mathrm{A}$ aprovação, sem reserva, das demonstrações financeiras e das contas, exonera de responsabilidade os administradores e fiscais, salvo erro, dolo, fraude ou simulação (artigo 286). 


\section{CAPÍTULO 4 - DEVERES DO CONSELHEIRO FISCAL}

\subsection{Deveres Fiduciários}

Conforme disposto no caput do art. 165 da lei societária, os membros do conselho fiscal têm os mesmos deveres dos administradores dispostos nos arts. $153^{48}$ e $156^{49}$, que regulam os deveres de diligência, de exercer as atribuições no interesse da companhia, de lealdade e de anulabilidade de voto conferido.

"Os principais deveres impostos por lei aos administradores de companhia são os de diligência, cumprimento das finalidades da empresa, lealdade e informar, elencados a partir do art. 153 da LSA", segundo as lições de Fabio Ulhoa Coelho ${ }^{50}$.

O dever de diligência, previsto no art. 153 da lei societária se traduz no exercício adequado de suas funções pelo administrador. Reza a norma que: “Art. 153. O administrador da companhia deve empregar, no exercício de suas funções, o cuidado e diligência que todo homem ativo e probo costuma empregar na administração dos seus próprios negócios." (Grifou-se)

O referido dever se expressa pelo standard do bom pai de família ou bom homem de negócios, que age de forma profissional e competente, de acordo com a finalidade, os interesses e a função social da companhia.

\footnotetext{
48 Art. 153. O administrador da companhia deve empregar, no exercício de suas funções, o cuidado e diligência que todo homem ativo e probo costuma empregar na administração dos seus próprios negócios.

49 Art. 156. É vedado ao administrador intervir em qualquer operação social em que tiver interesse conflitante com o da companhia, bem como na deliberação que a respeito tomarem os demais administradores, cumprindo-lhe cientificá-los do seu impedimento e fazer consignar, em ata de reunião do conselho de administração ou da diretoria, a natureza e extensão do seu interesse.

$\S 1^{\circ}$ Ainda que observado o disposto neste artigo, o administrador somente pode contratar com a companhia em condições razoáveis ou eqüitativas, idênticas às que prevalecem no mercado ou em que a companhia contrataria com terceiros.

$\S 2^{\circ} \mathrm{O}$ negócio contratado com infração do disposto no $\S 1^{\circ}$ é anulável, e o administrador interessado será obrigado a transferir para a companhia as vantagens que dele tiver auferido.

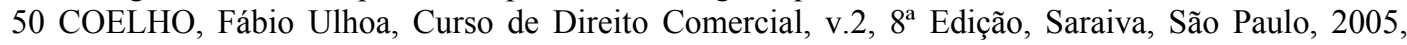
p. 243
} 
O dever de diligência atribuído aos administradores tem o sentido de cuidado ativo, zelo, sendo um padrão de comportamento expressado pela aplicação destes conceitos à própria gestão da Companhia. Nesta linha, o processo de tomada de decisão, para cumprir o seu dever de lealdade e diligência, revela-se na decisão informada, refletida e desinteressada.

A CVM já se pronunciou em diferentes Processos Administrativos Sancionadores, na qual a observância desses valores e padrões isenta a culpa do administrador.

Nesta linha, a CVM admitiu no caso Cataguazes ${ }^{51}$, que a jurisprudência americana em nada discrepa do que dispõe o art. 153 da lei societária, sendo possível utilizar-se, no Brasil, dos mesmos Standards de conduta aplicados nos $\mathrm{EUA}^{52}$.

Os deveres fiduciários aos quais estão submetidos os administradores decorrem de sua situação jurídica do poder de dispor de bens alheios, como um verdadeiro proprietário, em razão do exercício da gestão societária, respaldada pela lei societária e pelo estatuto social.

Ao administrador, contudo, não basta ser diligente. É preciso ser competente e profissional, como esclarece Flavia Parente ${ }^{53}$ :

"O dever de diligência dos administradores, no entanto, distingue-se do dever de diligência dos demais devedores de obrigações em geral, uma vez que se exige deste últimos a diligência de um bom pai de família, enquanto aos primeiros, atualmente, impõe-se algo mais que a simples conduta como bônus parte famílias - requer-se dos administradores, nos dias de hoje, como será examinado adiante, uma atuação competente e profissional"

Ademais, a regra fundamental do qual é extraído o padrão de comportamento exigido dos administradores é o dever de lealdade, positivado

\footnotetext{
${ }^{51}$ PAS CVM RJ2005/1443

52 PARENTE, Norma Jonssen. Mercado de Capitais / Norma Jonssen Parente; coordenação Modesto Carvalhosa. - São Paulo: Editora Revista dos Tribunais, 2016. (Coleção tratado de direito empresarial. v. 6). p.544.

53 PARENTE, Flávia, O dever de diligência dos Administradores de Sociedades Anônimas, Renovar, 2005, p.40 e 41
} 
no arts. $154^{54}$ e $155^{55}$ da lei societária, ao qual dispõe que é vedado aos administradores buscar os seus interesses pessoais ao gerirem a companhias, em detrimentos desta e de seus acionistas.

São deveres fiduciários que devem ser observados inter corpus e na representação da companhia perante terceiros.

O administrador deve: (a) exercer as atribuições que a lei e o estatuto social the conferem para os fins e no interesse da companhia, satisfeitas as exigências do bem público e da função social da empresa, não podendo, ainda que para a defesa do interesse dos que o elegeram, faltar a esses deveres; e (b)

54 Art. 154. O administrador deve exercer as atribuições que a lei e o estatuto lhe conferem para lograr os fins e no interesse da companhia, satisfeitas as exigências do bem público e da função social da empresa.

$\S 1^{\circ} \mathrm{O}$ administrador eleito por grupo ou classe de acionistas tem, para com a companhia, os mesmos deveres que os demais, não podendo, ainda que para defesa do interesse dos que o elegeram, faltar a esses deveres.

$\S 2^{\circ}$ É vedado ao administrador:

a) praticar ato de liberalidade à custa da companhia;

b) sem prévia autorização da assembléia-geral ou do conselho de administração, tomar por empréstimo recursos ou bens da companhia, ou usar, em proveito próprio, de sociedade em que tenha interesse, ou de terceiros, os seus bens, serviços ou crédito;

c) receber de terceiros, sem autorização estatutária ou da assembléia-geral, qualquer modalidade de vantagem pessoal, direta ou indireta, em razão do exercício de seu cargo.

$\S 3^{\circ}$ As importâncias recebidas com infração ao disposto na alínea c do $\S 2^{\circ}$ pertencerão à companhia. $\S 4^{\circ} \mathrm{O}$ conselho de administração ou a diretoria podem autorizar a prática de atos gratuitos razoáveis em benefício dos empregados ou da comunidade de que participe a empresa, tendo em vista suas responsabilidades sociais.

55 Art. 155. O administrador deve servir com lealdade à companhia e manter reserva sobre os seus negócios, sendo-lhe vedado:

I - usar, em benefício próprio ou de outrem, com ou sem prejuízo para a companhia, as oportunidades comerciais de que tenha conhecimento em razão do exercício de seu cargo;

II - omitir-se no exercício ou proteção de direitos da companhia ou, visando à obtenção de vantagens, para si ou para outrem, deixar de aproveitar oportunidades de negócio de interesse da companhia;

III - adquirir, para revender com lucro, bem ou direito que sabe necessário à companhia, ou que esta tencione adquirir.

$\S 1^{\circ}$ Cumpre, ademais, ao administrador de companhia aberta, guardar sigilo sobre qualquer informação que ainda não tenha sido divulgada para conhecimento do mercado, obtida em razão do cargo e capaz de influir de modo ponderável na cotação de valores mobiliários, sendo-lhe vedado valer-se da informação para obter, para si ou para outrem, vantagem mediante compra ou venda de valores mobiliários.

$\S 2^{\circ} \mathrm{O}$ administrador deve zelar para que a violação do disposto no $\S 1^{\circ}$ não possa ocorrer através de subordinados ou terceiros de sua confiança.

$\S 3^{\circ}$ A pessoa prejudicada em compra e venda de valores mobiliários, contratada com infração do disposto nos $\S \S 1^{\circ}$ e $2^{\circ}$, tem direito de haver do infrator indenização por perdas e danos, a menos que ao contratar já conhecesse a informação.

§ 4o É vedada a utilização de informação relevante ainda não divulgada, por qualquer pessoa que a ela tenha tido acesso, com a finalidade de auferir vantagem, para si ou para outrem, no mercado de valores mobiliários. (Incluído pela Lei n ${ }^{\circ} 10.303$, de 2001) 
servir com lealdade à companhia, não se omitindo no exercício ou proteção de seus direitos (arts. 154, caput e $\S 1^{\circ}$, e 155, caput e inciso II).

A especificação desses deveres na lei 6.404/76 não é exaustiva, mas resultam de princípios que abrangem deveres derivados ou correlatos, pois a noção básica é que estes, no exercício de suas atribuições, devem agir sempre com lisura, cuidado e prudência (adotando as cautelas necessárias), com diligência (sem negligência), com aptidão (sem imperícia).

O padrão a ser seguido por um administrador é de um profissional competente, que atue com observância do fim inerente às suas atribuições e sem desvio de poder. Esse é o princípio que está na essência da posição jurídica de administrador membro de Conselho de Administração ou da Diretoria, ou na posição jurídica de membro do Conselho Fiscal.

O poder-dever de fiscalização do conselheiro fiscal demanda que o conselheiro fiscal se mantenha sempre em estado de alerta para investigar e averiguar qualquer indício de irregularidade, sendo sua conduta pautada pela independência, boa-fé e lealdade, sempre no melhor interesse da companhia.

Nesta linha, o dever de diligência aplicado ao membro do colegiado fiscal pressupõe sua disponibilidade, competência técnica e amplo conhecimento sobre as atividades da sociedade sob sua supervisão, uma vez que cumprindo este dever de informação o conselheiro terá a capacidade de para supervisionar as atividades da companhia e sua evolução de sua situação financeira.

\subsection{Dever De Investigar}

Ademais, há o dever de investigar, no qual o deve o membro do colegiado, dentro dos limites de sua competência, analisar criticamente as informações que recebe e sobre as quais deva opinar. Para o melhor desempenho de suas funções, no caso da necessidade de se apurar um fato complexo ou que não seja do seu campo de conhecimento, pode o conselheiro 
requisitar à companhia a contratação de perito para auxilia-lo, nos termos do art. $163, \S 8^{\circ}$, bem como solicitar a contratação de contador caso a companhia não tenha auditor independente, nos termos do art. $163, \S 5^{\circ}$.

O dever de Investigar não acarreta a responsabilidade automática do membros do conselho fiscal por qualquer ato ilegal dos administradores, nos quais em princípio, ele pode legitimamente confiar. Com efeito, cabe-lhe investigar com maior profundidade na presença das chamadas red flags, ou seja, de sinais de alerta de que ilegalidades podem estar sendo cometidas ${ }^{56}$.

\subsection{Dever De Informar}

O dever de informar classicamente está relacionado à necessária transparência dos negócios da sociedade anônima, sendo imperativo que o administrador, sempre de forma imediata, informe aos acionistas sobre fatos relevantes; ao mercado sobre qualquer deliberação do órgão gestor que possa influir significativamente no comportamento dos investidores (art. 157, $4^{\circ}$ ), ainda, ainda sobre eventuais interesses que possua nos negócios sociais da companhia (art. 157, caput e $§ 1$ ).

Os conselheiros físcais não estão submetidos ao dever de informar previsto no art. $157^{57}$ da lei societária, como estão os outros administradores,

56 EIZIRIK, Nelson. A Lei das S/A Comentada. Volume II - Artigos 121 a 188. São Paulo: Quartier Latin, 2011, p. 460

57 Art. 157. O administrador de companhia aberta deve declarar, ao firmar o termo de posse, o número de ações, bônus de subscrição, opções de compra de ações e debêntures conversíveis em ações, de emissão da companhia e de sociedades controladas ou do mesmo grupo, de que seja titular. (Vide Lei no 12.838 , de 2013)

$\S 1^{\circ} \mathrm{O}$ administrador de companhia aberta é obrigado a revelar à assembleia-geral ordinária, a pedido de acionistas que representem 5\% (cinco por cento) ou mais do capital social:

a) o número dos valores mobiliários de emissão da companhia ou de sociedades controladas, ou do mesmo grupo, que tiver adquirido ou alienado, diretamente ou através de outras pessoas, no exercício anterior;

b) as opções de compra de ações que tiver contratado ou exercido no exercício anterior;

c) os benefícios ou vantagens, indiretas ou complementares, que tenha recebido ou esteja recebendo da companhia e de sociedades coligadas, controladas ou do mesmo grupo;

d) as condições dos contratos de trabalho que tenham sido firmados pela companhia com os diretores e empregados de alto nível; 
mas são obrigados à informar imediatamente as modificações e suas posições acionarias da companhia à CVM e entidade em que os valores mobiliários de emissão da companhia estejam admitidos à negociação, nos termos do art. 165$\mathrm{A}^{58}$ da lei societária.

Tal norma tem por objetivo evitar que os conselheiros fiscais usem informações privilegiadas, em proveito próprio ou de terceiros, mediante a compra e venda de valores mobiliários. Os membros do colegiado são considerados insiders primários, uma vez que tem acesso direto às informações confidenciais da companhia no exercício de suas funções.

Para o conselheiro fiscal, correm outros deveres anexos, como os deveres de conselho, alerta e de informar-se.

O dever de se informar para o conselheiro fiscal consiste na obtenção de todas as informações e dados necessários para o adequado desempenho de suas funções, devendo ter conhecimento dos negócios e operações desenvolvidas pela companhia, dos atos societários. $\mathrm{O}$ dever de se informar para informar faz

e) quaisquer atos ou fatos relevantes nas atividades da companhia.

$\S 2^{\circ}$ Os esclarecimentos prestados pelo administrador poderão, a pedido de qualquer acionista, ser reduzidos a escrito, autenticados pela mesa da assembléia, e fornecidos por cópia aos solicitantes.

$\S 3^{\circ}$ A revelação dos atos ou fatos de que trata este artigo só poderá ser utilizada no legítimo interesse da companhia ou do acionista, respondendo os solicitantes pelos abusos que praticarem.

$\S 4^{\circ}$ Os administradores da companhia aberta são obrigados a comunicar imediatamente à bolsa de valores e a divulgar pela imprensa qualquer deliberação da assembléia-geral ou dos órgãos de administração da companhia, ou fato relevante ocorrido nos seus negócios, que possa influir, de modo ponderável, na decisão dos investidores do mercado de vender ou comprar valores mobiliários emitidos pela companhia.

$\S 5^{\circ}$ Os administradores poderão recusar-se a prestar a informação ( $\S 1^{\circ}$, alínea e), ou deixar de divulgá-la $\left(\S 4^{\circ}\right)$, se entenderem que sua revelação porá em risco interesse legítimo da companhia, cabendo à Comissão de Valores Mobiliários, a pedido dos administradores, de qualquer acionista, ou por iniciativa própria, decidir sobre a prestação de informação e responsabilizar os administradores, se for o caso.

§ 6o Os administradores da companhia aberta deverão informar imediatamente, nos termos e na forma determinados pela Comissão de Valores Mobiliários, a esta e às bolsas de valores ou entidades do mercado de balcão organizado nas quais os valores mobiliários de emissão da companhia estejam admitidos à negociação, as modificações em suas posições acionárias na companhia. (Incluído pela Lei $\mathrm{n}^{\mathrm{o}} 10.303$, de 2001)

58 Art. 165-A. Os membros do conselho fiscal da companhia aberta deverão informar imediatamente as modificações em suas posições acionárias na companhia à Comissão de Valores Mobiliários e às Bolsas de Valores ou entidades do mercado de balcão organizado nas quais os valores mobiliários de emissão da companhia estejam admitidos à negociação, nas condições e na forma determinadas pela Comissão de Valores Mobiliários. (Incluído pela Lei nº 10.303, de 2001) 
faz parte da diligência necessária para o eficaz cumprimento dos deveres de informação, conselho e alerta.

Considerando que os acionistas muitas vezes não têm conhecimento técnico sobre contabilidade ou finanças, bem como não tem real compreensão sobre a situação patrimonial da companhia, o aconselhamento pelo conselheiro fiscal, profissional especializado e informado sobre a real situação da companhia são de extrema importância para o pleno exercício dos direitos do acionista, revelando a importância dos deveres de alerta e conselho.

O dever de conselho consiste em uma obrigação de informar o acionista de modo que este possa compreender os dados e informações fornecidas e as consequências da situação nela descrita.

De forma diversa, o dever de alerta tem por objetivo orientar o acionista e o adverti-lo sobre os aspectos e riscos de determinada situação ou operação, com o finto de lhe fornecer informações prévias, de forma a se prevenir contra o risco de danos. 


\section{CAPÍTULO 5 - RESPONSABILIDADE DO CONSELHEIRO FISCAL}

A lei societária equiparou a responsabilidade dos membros do conselho fiscal à dos membros da administração previsto no art. $158^{59}$. Desta forma, conforme disposto no caput do art. 165, eles respondem pelos danos resultantes de omissão no cumprimento de seus deveres praticados com culta e dolo, ou com violação da lei ou do estatuto.

No âmbito do Conselho Fiscal, se dá ênfase ao atos omissivos, quando o conselheiro por exemplo (i) deixa de apresentar representação à assembleia geral sobre constatação de atos irregulares promovidos pela administração (art. 163, IV, e 164, parágrafo único); deixar de votar em reunião do Conselho Fiscal matéria opinativa ou deliberativa, que saiba ser necessária ao interesse social (art. 163, II e III); e (iii) não comparecer à reunião ou não diligenciar junto à administração quando sabe da existência de atos e fatos danosos à companhia (art. $\left.163, \S 2^{\circ}\right)$.

59 Art. 158. O administrador não é pessoalmente responsável pelas obrigações que contrair em nome da sociedade e em virtude de ato regular de gestão; responde, porém, civilmente, pelos prejuízos que causar, quando proceder:

I - dentro de suas atribuições ou poderes, com culpa ou dolo;

II - com violação da lei ou do estatuto.

$\S 1^{\circ} \mathrm{O}$ administrador não é responsável por atos ilícitos de outros administradores, salvo se com eles for conivente, se negligenciar em descobri-los ou se, deles tendo conhecimento, deixar de agir para impedir a sua prática. Exime-se de responsabilidade o administrador dissidente que faça consignar sua divergência em ata de reunião do órgão de administração ou, não sendo possível, dela dê ciência imediata e por escrito ao órgão da administração, no conselho fiscal, se em funcionamento, ou à assembléia-geral.

$\S 2^{\circ}$ Os administradores são solidariamente responsáveis pelos prejuízos causados em virtude do não cumprimento dos deveres impostos por lei para assegurar o funcionamento normal da companhia, ainda que, pelo estatuto, tais deveres não caibam a todos eles.

$\S 3^{\circ}$ Nas companhias abertas, a responsabilidade de que trata o $\S 2^{\circ}$ ficará restrita, ressalvado o disposto no $\S 4^{\circ}$, aos administradores que, por disposição do estatuto, tenham atribuição específica de dar cumprimento àqueles deveres.

$\S 4^{\circ} \mathrm{O}$ administrador que, tendo conhecimento do não cumprimento desses deveres por seu predecessor, ou pelo administrador competente nos termos do $\S 3^{\circ}$, deixar de comunicar o fato a assembléia-geral, tornar-se-á por ele solidariamente responsável.

$\S 5^{\circ}$ Responderá solidariamente com o administrador quem, com o fim de obter vantagem para si ou para outrem, concorrer para a prática de ato com violação da lei ou do estatuto. 
Conforme leciona Carvalhosa ${ }^{60}$ :

"A responsabilidade do conselheiro por omissão deve ser analisada sob o regime de presunção de culpa, se estabelecendo o nexo causal entre o dano e a culpa do conselheiro, nos termos do art. $186^{61}$ do Código Civil, pelo não cumprimento do seu dever de diligencia, ou seja, pelo ato ilícito cometido pelo conselheiro ao não pautar sua conduta pelo constante estado de alerta que lhe é exigido"

A responsabilidade dos conselheiros fiscais, tratando de atos omissivos, é a princípio individual, respondendo cada membro do colegiado pelos seus próprios atos. Entretanto, há a possibilidade de responsabilidade solidária caso fique judicialmente comprovado que houve conluio ou conivência com outros conselheiros, administradores ou controladores, conforme disposto no $\S 3^{\circ}$ do art. $165^{63}$.

Entre os conselheiros fiscais, a solidariedade é decorrente do descumprimento ou omissão dos seus deveres no exercício de suas funções, principalmente no que tange aos deveres legais previstos no art. 163 da lei societária.

Se os conselheiros se omitem no cumprimento de seus deveres, há uma presunção de sua responsabilidade solidária, podendo ser exonerados os conselheiros que ativamente se opuseram ou se omitiram da prática do ato danoso, manifestando em ata sua divergência e a comunicando aos órgãos da administração e assembleia geral.

60 Carvalhosa, M., \& Kuyven, L. F. (2016). Sociedades Anônimas (Coleção Tratado de Direito Empresarial) (Vol. 3). São Paulo: Revista dos Tribunais,. p. 953

61 Art. 186. Aquele que, por ação ou omissão voluntária, negligência ou imprudência, violar direito e causar dano a outrem, ainda que exclusivamente moral, comete ato ilícito.

${ }^{63}$ Art. 165. (...)

§ 30 A responsabilidade dos membros do conselho fiscal por omissão no cumprimento de seus deveres é solidária, mas dela se exime o membro dissidente que fizer consignar sua divergência em ata da reunião do órgão e a comunicar aos órgãos da administração e à assembléia-geral. (Incluído pela Lei $\mathrm{n}^{\circ}$ 10.303, de 2001) 


\section{CAPÍTULO 6 - ABUSO NO EXERCICIO DA FUNÇÃO DE CONSELHEIRO FISCAL}

Conforme disposto no art. $165, \S 1^{\mathrm{o}^{64}}$ da lei societária, os membros do Conselho Fiscal deverão exercer suas atribuições no exclusivo interesse da companhia, considerando-se abusivo o exercício de tal função com o objetivo de causar dano à sociedade, aos seus acionistas, ou aos seus administradores, ou de obter vantagem indevida.

Vale lembrar que após a sua eleição, os membros do Conselho Fiscal devem passar agir, somente e sempre, no exclusivo interesse da sociedade, e não do grupo de acionistas que o elegeu.

Desta forma, foi criada a figura do abuso no exercício da função de conselheiro fiscal que na lição de Modesto Carvalhosa ${ }^{65}$ :

"é caracterizada quando o Conselheiro Fiscal utiliza suas prerrogativas legais com o fim de causar dano à companhia ou de obter vantagem para si ou para outrem, em detrimento da companhia, de seus acionistas ou de seus controladores."

O abuso no exercício da função de conselheiro fiscal pode ser praticado tanto pelos conselheiros eleitos pelos acionistas controladores como minoritários.

Para Lamy Filho ${ }^{66}$ :

\footnotetext{
${ }^{64}$ Art. 165. (...)

$\S 10$ Os membros do conselho fiscal deverão exercer suas funções no exclusivo interesse da companhia; considerar-se-á abusivo o exercício da função com o fim de causar dano à companhia, ou aos seus acionistas ou administradores, ou de obter, para si ou para outrem, vantagem a que não faz jus e de que resulte, ou possa resultar, prejuízo para a companhia, seus acionistas ou administradores. (Redação dada pela Lei ${ }^{\circ} 10.303$, de 2001)

65 Carvalhosa, M., \& Kuyven, L. F. (2016). Sociedades Anônimas (Coleção Tratado de Direito Empresarial) (Vol. 3). São Paulo: Revista dos Tribunais,. p. 948

66 LAMY FILHO, Alfredo. In: Lamy Filho, Alfredo e Bulhões Pedreira, José Luiz. Direito das Companhias. Rio de Janeiro: Forense, 2009 vol. 1, p. 1286
} 
"a experiência do funcionamento do Conselho Fiscal mostra que os atos ilícitos dos membros do Conselho eleitos pela maioria dos acionistas são em regra de omissão no exercício das suas funções, enquanto os dos eleitos pela minoria ou por ações preferenciais são de exercício abusivo das suas atribuições, especialmente as de pedir esclarecimentos ou informações aos órgãos da administração ou a auditores independentes e de denunciar erros, fraudes ou crimes aos órgãos da administração ou à assembleia geral"

Se por um lado as reformas societárias supracitadas reafirmaram as competências individuais do conselheiro fiscal, por outro estipulou outras com objetivo de impedir que esta seja usada por minoritários agressivos como método ilegítimo de pressionar na administração, com o objetivo de forçar o acionista controlador a adquirir as ações de acionistas, ou thes pagar um valor maior em oferta pública para fechamento da companhia ou em deliberações da Assembleia que dão direito de retirada aos dissidentes.

Para conter este exercício abusivo, conforme já explicitado, o $\S 2^{\circ}$ do art. 163 prevê de forma clara que as solicitações feitas por qualquer dos membros do Conselho Fiscal aos administradores da companhia deverão ser estritamente relativos à sua função fiscalizadora, sendo restrita à gestão financeira da sociedade controladora e suas controladas, direta ou indiretamente.

O abuso no exercício da função de conselheiro fiscal não se presume, cabendo o ônus da prova a quem o alega, sob pena de cerceamento ilegal à atividade fiscalizatória legitimamente exercida pelos membros e pelo órgão. 


\section{CONCLUSÃO}

O conselho fiscal representa a opção do legislador em limitar a participação direta dos acionistas na fiscalização da gestão das atividades sociais, tendo em vista a complexa estrutura das sociedades anônimas.

A função essencial do conselho fiscal, conforme supracitado, é a de exercer a permanente fiscalização sobre os atos da administração da companhia (conselho de administração e/ou diretoria), sob o controle das finanças da companhia e a legalidade e regularidade dos atos de gestão.

Neste contexto, a lei societária optou pelo regime da autonomia individual dos conselheiros fiscais, uma vez que a competência colegial do Conselho Fiscal para todas as suas funções poderia significar a opressão do representante dos acionistas minoritários.

Ademais, o poder individual de diligencia dos seus membros reforça o poder fiscalizatório do órgão, que tem por objetivo transmitir aos acionistas as informações que necessitam, quer para exercerem o direito de voto, com substancial conhecimento do que vem a ser deliberado, quer para fiscalizarem a gestão dos negócios sociais, de forma a se resguardar os direitos essenciais dos acionistas da companhia. 


\section{BIBLIOGRAFIA}

CARVALHOSA, M., \& Kuyven, L. F. (2016). Sociedades Anônimas (Coleção Tratado de Direito Empresarial) (Vol. 3). São Paulo: Revista dos Tribunais

CARVAlHOSA, Modesto, Comentários à Lei de Sociedades Anônimas. $3^{\circ}$ Volume - Edição revista e atualizada - Artigos 138 a 205, 5 a edição - Editora Saraiva, São Paulo, 2011

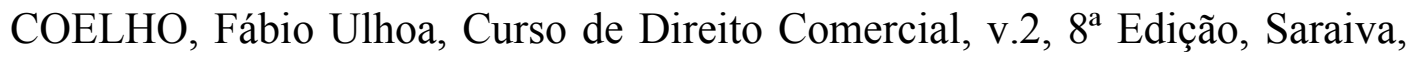
São Paulo, 2005,

DA SILVA, Américo Luis Martins. Sociedades Empresarias. $1^{\text {a }}$ ed. Rio de Janeiro: Forense, 2007.

EIZIRIK, Nelson. A Lei das S/A Comentada. Volume II — Artigos 121 a 188. São Paulo: Quartier Latin, 2011

LAMY FILHO, Alfredo. In: Lamy Filho, Alfredo e Bulhões Pedreira, José Luiz. Direito das companhias. Rio de Janeiro: Forense, 2009 vol 1

PARENTE, Flávia, O dever de diligência dos Administradores de Sociedades Anônimas, Renovar, 2005,

PARENTE, Norma Jonssen. Mercado de Capitais / Norma Jonssen Parente; coordenação Modesto Carvalhosa. - São Paulo: Editora Revista dos Tribunais, 2016. (Coleção tratado de direito empresarial. v. 6). 